\title{
Person of the Month: Jacques Lacan (1901-1981)
}

\section{Ankit Patel ${ }^{1}$}

\begin{tabular}{|c|c|}
\hline \multirow[t]{2}{*}{ Born } & 13 April 1901 \\
\hline & Paris, France \\
\hline \multirow[t]{2}{*}{ Died } & 9 September 1981 \\
\hline & Paris, France \\
\hline Citizenship & French \\
\hline Known for & $\begin{array}{l}\text { Mirror phase, The Real, The Symbolic } \\
\text { The Imaginary, Graph of desire }\end{array}$ \\
\hline Fields & Psychoanalysis \\
\hline
\end{tabular}

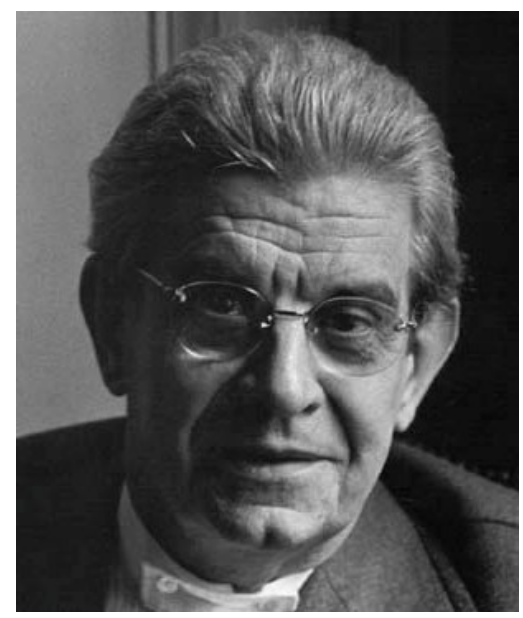

Jacques Lacan, in full Jacques Marie Émile Lacan (born April 13, 1901, Paris, France-died Sept. 9, 1981, Paris) French psychoanalyst who gained an international reputation as an original interpreter of Sigmund Freud's work.

Lacan earned a medical degree in 1932 and was a practicing psychiatrist and psychoanalyst in Paris for much of his career. He helped introduce Freudian theory into France in the 1930s, but he reached prominence only after he began conducting regular seminars at the University of Paris in 1953. He acquired celebrity status in France after the publication of his essays and lectures in Écrits (1966). He founded and headed an organization called the Freudian School of Paris from 1964 until he disbanded it in 1980 for what he claimed was its failure to adhere with sufficient strictness to Freudian principles.

Lacan's avowed theoretical intention, from at least 1953, was the attempt to reformalize what he termed "the Freudian field." His substantial corpus of writings, speeches and seminars can be read as an attempt to unify and reground what are the four interlinking aspirations of Freud's theoretical writings:

\footnotetext{
${ }^{1}$ Clinical Psychology, Dept. of Psychology, Sardar Patel University, Vallabh Vidyanagar, Gujarat

(C) 2016 A Patel; licensee IJIP. This is an Open Access Research distributed under the terms of the Creative Commons Attribution License (http://creativecommons.org/licenses/by/2.0), which permits unrestricted use, distribution, and reproduction in any Medium, provided the original work is properly cited.
} 
- a theory of psychoanalytic practice as a curative procedure;

- the generation of a systematic metapsychology capable of providing the basis for

- the formalization of a diagnostic heuristic of mental illness; and

- the construction of an account of the development of the "civilized" human psyche.

Lacan's failing health made it difficult for him to meet the demands of the year-long Seminars he had been delivering since the fifties, but his teaching continued into the first year of the eighties. After dissolving his School, the EFP, in January 1980, Lacan travelled to Caracas to found the Freudian Field Institute on 12 July. The Overture to the Caracas Encounter was to be Lacan's final public address. His last texts from the spring of 1981 are brief institutional documents pertaining to the newly formed Freudian Field Institute and Lacan died on 9 September 1981.

\section{TIMELINE}

1901

- Jacques-Marie-Émile Lacan is born in Paris, April 13, to a family of solid Catholic tradition. He is educated at the Collège Stanislas, a Jesuit school. He has a sister, Magdeleine-Marie and a younger brother Marc-Marie, who later becomes a Benedictine at the abbey of Hautecombe. His brother's name appears before those of his parents in his thesis dedication. After his baccalauréat he studies medicine and later psychiatry.

- Starts clinical training, works at Sainte-Anne's hospital in the second section of women and in the Clinic for Mental and Encephalic Diseases directed by Professor Henri Claude. A year later he works in the Special Infirmary Service where Clérambault had a practice. Up to 1932 Lacan was involved in the Societé Neurologique, the Société de Psychiatrie and the Société Clinique de Médecine mentale, he was fully integrated in the official circles of neurology and psychiatry.

- Lacan presents some of his hypotheses at the Evolution Psychiatrique and publishes the following year in the Revue française de psychanalyse his translation of Freud's "On Some Neurotic Mechanisms in Jealousy, Paranoia and Homosexuality." Receives a diploma as a forensic psychiatrist. He publishes Structure des psychoses paranoïaques, Semaine des Hôpitaux de Paris, 7 July 1931.

- Awarded doctorate for his thesis: De la psychose paranoïaque dans ses rapports avec la personalité, Paris: Le Français, 1932. Later though (1975) he will state that paranoid psychosis and personality are the same thing. One name stands out by its absence from the list of dedication: that of Clérambault. It was because of their differences that Lacan failed his agrégation. At that time Lacan declares that in his thesis he was against "mental automatism," Clérambault's theory. 
- Because of his thesis he becomes a specialist in paranoia. The richness of his text and the multiplicity of its aspects appealed to very different circles, especially the analysis of the case of Aimée make him famous with the Surrealists. Between this year and 1939, he takes Kojève's course at the Ecole Pratique des Hautes Etudes, an "Introduction to the Reading of Hegel." He publishes Motifs du crime paranoïque: le crime des soeurs Papin. Minotaure.

- He is appointed doctor of the Asiles, and marries Marie-Louise Blondin, mother of Caroline, Thibaut and Sibylle. While in analysis with Rudolph Loewenstein, Lacan becomes a member of La Société Psychoanalytique de Paris (SPP). Loewenstein is one of the four training analysts of the S.P.P. His analysis ends in 1939 with Loewenstein's departure to the war.

1938

- Becomes a full member of the SPP. Lectures at the S.P.P. on De l'impulsion au complexe where he argues for a "primordial structural stage" called "stage of the fragmented body in the development of the ego." At this stage "pure drives" (la pulsion à l'état pur) would appear in states of "horror" inseparable from a "passive beatitude." To defend his thesis, he presents two cases of patients at length. He publishes La famille: Encyclopédie française, Vol. 8.

1940

- Works at Val-de-Grâce, the military hospital in Paris. During the German Occupation, he does not partake in any official activity. "For several years I have kept myself from expressing myself. The humiliation of our time under the subjugation of the enemies of human kind dissuaded me from speaking up, and following Fontenelle, I abandoned myself to the fantasy of having my hand full of truths so as to better close it on them." In "Propos sur la causalité psychique," from 1946 and published in Écrits.

1947

- In 1946, the S.P.P. resumes its activities and Lacan, with Nacht and Lagache, takes charge of training analyses and supervisory controls and plays an important theoretical and institutional role. After visiting London in 1945 he publishes La Psychiatrique anglaise et la guerre, in Evolution psychiatrique1.

- The S.P.P. begins to raise the issue of Lacan's short sessions, as opposed to the standard analytical hour. Lacan argues that his technique accelerates analysis. The underlying logic is that if the unconscious itself is timeless, it makes no sense to insist upon standard sessions. Lacan defends his use of short sessions a year later in La psychanalyse, dialectique?, unpublished. 
- During this period of crisis at the S.P.P. (1951-52), the responsibility for the report on the 1953 conference in Rome "Fonction et champ de la parole et du langage" is assigned to Lacan. At the time he is considered to be the most productive and original theoretician of the group, all the more so because he always uses the classical terms of the Freudian orthodoxy when speaking within the S.P.P.

- In his project for the statutes of the S.P.P. Lacan organizes the curriculum around four types of seminars: commentaries of the official texts (particularly Freud's), courses on controlled technique, clinical and phenomenological critique, and child analysis. A large amount of freedom of choice is left to students in training. In January Lacan is elected President of the S.P.P. Six months later he resigns to join the Société Française de Psychanalyse (S.F.P.) with D. Lagache, F. Dolto, J. Favez-Boutonier among others. (At S.F.P.'s first meeting, Lacan lectures on "Le Symbolique, l'Imaginaire et le Réel"). Nevertheless the S.F.P. is allowed to be present in Rome where Lacan delivers his report: "Fonction et champ de la parole et du langage," discourse in which, for once, remarks Lagache with humor, "he is in no way Mallarmean." On July 17 he marries Sylvia Maklès, mother of Judith. That Fall Lacan starts his seminars at the Hôpital Sainte-Anne.

- The Neurotic's Individual Myth: Psychoanalytic Quarterly, 1979.

- 1954The positive reception of the expression "the return to Freud" and of his report and discourse in Rome give Lacan the will to reelaborate all the analytical concepts. His critique of analytic literature and practice spares almost nobody. Lacan returns to Freud yet his return is a re-reading in relation with contemporary philosophy, linguistics, ethnology, biology and topology. At Sainte-Anne he held his seminars every Wednesday and presents cases of patients on Fridays.

- Lacan will remain at Sainte-Anne till 1963. The first ten Seminars elaborate fundamental notions about psychoanalytic technique, the essential concepts of psychoanalysis, and even its ethics. Students give presentations yet it is the Tuesday night conferences that fed Lacan's commentaries on Wednesdays.

- Le séminaire, Livre II: Le moi dans la téorie de Freud et dans la technique de la psychanalyse, Paris: Seuil, 1978; The Seminar, Book II: The Ego in Freud's Theory and in the Technique of Psychoanalysis, 1954 - 55, New York: Norton, 1988.

- "The flexibility of the S.F.P. increases Lacan's audience. Celebrities are attracted to his seminars (Hyppolite's analysis of Freud's article on Dénégation, given during the first seminar, is a well-known example). Koyré on Plato, Lévi-Strauss, Merleau-Ponty, Griaule, the ethnologist, Benvéniste among others attend his courses. 
- "Fetishism: The Symbolic, The Real and The Imaginary" (in collaboration with W. Granoff), in S. Lorand and M. Balint, eds.,Perversions: Psychodynamics and Therapy, New York: Random House, 1956.

1957

- During this period Lacan writes, on the basis of his seminars, conferences and addresses in colloquia, the major texts that are found in Écrits in 1966. He publishes in a variety of journals, notably in L'Evolution Psychiatrique, which takes no account of the S.P.P. / S.F.P. conflict and Bulletin de la Société de Philosphie. J.B. Pontalis, Lacan's student, publishes with his consent the accounts of Seminars IV, V and VI in Bulletin de Psychanalyse

1958

- In the S.P.P. executive board, positions and titles are exchanged with perfect regularity until Serge Leclaire becomes secretary and then president. Yet Lacan emerges, if not the only thinker of the group, at least as the one who has the largest audience and the most audacity, especially since his practice of short sessions secures him the greatest number of analysts-in-training. A Lacan group begins to organize itself, identifiable by its language and its modes of intervention in discussions.

- The first issue of La Psychanalyse from 1956 is entirely devoted to Lacan: it includes the Rome report and discourse with the discussions that followed with Lacan's response, the commentaries from Seminar I on Hyppolite's analysis of denegation and Lacan's translation of Heidegger's Logos. In a following issue Hesnard will comment on Wo es war, soll Ich werden that according to Lacan the "I" must come to the place where the id was: là où était le "ça" "je” dois advenir. This opposes the S.P.P.'s translation: "the ego must drive out the id."

- Le séminaire, Livre VI: Le désir et son interpretation, unpublished.

1960

- In his Ethics Lacan defines the true ethical foundations of psychoanalysis and constructs an ethics for our time, an ethics that would prove to be equal to the tragedy of modern man and to the "discontent of civilization" (Freud). At the roots of the ethics is desire: analysis' only promise is austere, it is the entrance-into-the-I, l'entrée-en-Je. "I must come to the place where the id was," where the analysand discovers, in its absolute nakedness, the truth of his desire. The end of psychoanalysis entails "the purification of desire." This text functions throughout the years as the background of Lacan's work.

- Le séminaire, Livre VII: L'éthique de la psychanalyse, Paris: Seuil, 1986.The Seminar, Book VII: The Ethics of Psychoanalysis, 1959-60, New York: Norton, 1992.

- At the colloquium on dialectic organized by Jean Wahl at Royaumont the previous year, Lacan defends three assertions: psychoanalysis, insofar as it elaborates its theory from its praxis, must have a scientific status; the Freudian discoveries have radically changed the 
concepts of subject, of knowledge, and of desire; the analytic field is the only one from where it is possible to efficiently interrogate the insufficiencies of science and philosophy. This major intervention will appear in Écrits as "Subversion of the Subject and Dialectic of Desire in the Freudian Unconscious," where the subject of psychoanalysis is neither Hegel's absolute subject nor the abolished subject of science. It is a subject divided by the emergence of the signifier. As to the subject of the unconscious, it is impossible to know who speaks. It is "the pure subject of the enunciation," which the pronoun "I" indicates but does not signify. Yet the key concept is that of desire: "it is precisely because desire is articulated that it is not articulable in a signifyng chain."

- Meanwhile S.F.P. members want to be recognized by the I.P.A. At the Congress of Edinburgh in 1961, the I.P.A. committee recommends that the S.F.P. become a supervised study group of the I.P.A. Moreover, in a series of twenty requirements it asks the S.F.P. to ban Lacan (also Dolto and Bergé) from the analysts' training: the problem of the short sessions, which was already at stake during the first split, is back for discussion. Lacan did not "give in on his desire," and neither did the I.P.A. make concessions about its principles. He was not banned from psychoanalytic practice nor from teaching: he was denied the right to train analysts. Driven to choose between Lacan and affiliation with the I.P.A., Paris opts for the time being not to make any decision. Moreover, a motion is adopted by the Bureau of the S.F.P. stating that "any attempt to force the expulsion of one of its founder members would be discriminatory, and would offend against both the principles of scientific objectivity and the spirit of justice." Lacan and Dolto are elected president and vice-president.

- Later that year, Lacan is appointed chargé de cours at the École Pratique des Hautes Etudes (Paris) and a series director at Éditions du Seuil. The series will be known as Le Champ freudien: in time his Seminars and Écrits will be published in there.

- Le séminaire, Livre IX: L'identification, unpublished.

- In January, Serge Leclaire succeeds Lacan as president of the S.F.P. In May, envoys from the I.P.A visit Paris and meet with Leclaire. Not only they express doubts about Lacan's attitude towards Freud (he studies Freud's texts obsessionally, in the manner of medieval scholar) they also claim that Lacan manipulates transference through the short session: he must be excluded from the training courses. At the Congress of Stockholm, in July, the I.P.A. votes an ultimatum: within three months Lacan's name has to be crossed off the list of didacticians. Everything is organized to reorient his students in training analysis towards others analysts, thanks to a committee supervised by the I.P.A. Two weeks before the expiration of the deadline fixed by the I.P.A. (October 31), Lagache, Granoff and Favez advance a motion calling for Lacan's name to be removed from the list of training analysts: the committee of didacticians of the S.F.P. gives up its courageous 


\section{Person of the Month: Jacques Lacan (1901-1981)}

position of 1962. On November 19 a general meeting has to make a final decision on I.P.A.'s conditions regarding Lacan. Lacan then writes a letter to Leclaire announcing he will not attend the meeting because he can foresee the disavowal. Thus, on November 19, the members' majority takes the position in favor of the ban. As a result of it Leclaire and Dolto resign from office. During the night Lacan learns the decision made at the meeting: he no longer is one of the didacticians. The next day, his seminar on "The Names-of-theFather" is to start at Sainte-Anne: he announces its end. Fragments of it are published in L'excommunication

1964

- Lacanians form a Study Group on Psychoanalysis organized by Jean Clavreul, until Lacan officially founds L'École Française de Psychanalyse. Soon it becomes L'École Freudienne de Paris (E.F.P.). "I hereby found the École Française de Psychanalyse, by myself, as alone as I have ever been in my relation to the psychoanalytic cause." The E.F.P. is organized on the basis of three sections: pure psychoanalysis (doctrine, training and supervision), applied psychoanalysis (the cure, casuistics, psychiatric information), and the Freudian field (commentaries on the psychoanalytic movement, articulation with related sciences, ethics of psychoanalysis).

- With Lévi-Strauss and Althusser's support, he is appointed lecturer at the École Pratique des Hautes Etudes. He begins his new seminar on "The Four Fundamental Concepts of Psychoanalysis" in January in the Dussane room at the École Normale Supérieure (in his first session he thanks the generosity of Fernand Braudel and Claude Lévi-Strauss).

- Le séminaire, Livre XI: Les quatre concepts fondamentaux de la psychanalyse, Paris: Seuil, 1973.The Seminar, Book XI: The Four Fundamental Concepts of Psychoanalysis, New York: Norton, 1981.

- Having founded his own école, Lacan's renown increases considerably in his new settings at the rue d'Ulm. He keeps presenting cases of patients at Sainte-Anne; members of his école work and teach in Paris in hospitals such as Trousseau, Sainte-Anne and Les Enfants Malades; and others join universities or hospitals in the provinces (Strasbourg, Montpellier, Lille). In his seminars he explains his project to teach "the foundations of psychoanalysis" as well as his position within the psychoanalytic institution. His audience is made of analysts but also of young students in philosophy at the E.N.S., notably Jacques-Alain Miller, to whom Althusser assigns the reading of "all of Lacan" and who actually does it. It is him who asks Lacan the famous question: "Does your notion of the subject imply an ontology?"

- Le séminaire, Livre XII: Problèmes cruciaux pour la psychanalyse, unpublished.

- Lacan wants to continue to train analysts, his first priority. Yet, at the same time, his teaching is addressed to the non analysts, and thus he raises these questions: Is psychoanalysis a science? Under what conditions is it a science? If it is-the "science of 


\section{Person of the Month: Jacques Lacan (1901-1981)}

the unconscious" or a "conjectural science of the subject"-what can it, in turn, teach us about science? Cahiers pour l'Analyse, the journal of the Cercle d'Epistémologie at the E.N.S. is founded by Alain Grosrichard, Alain Badiou, Jean-Claude Milner, François Regnault and Jacques-Alain Miller among others. It publishes texts by Lacan in three of its issues that very year. In July Judith Lacan marries Jacques-Alain Miller.

- Écrits, Paris: Seuil, 1966. Écrits, A Selection, New York: Norton, 1977. The French version immediately became a best-seller and draws considerable public attention to the école far beyond the intelligentsia.

- Le séminaire, Livre XIII: L'objet de la psychanalyse, unpublished.

- Lacan states in the Acte de Fondation that he shall undertake the direction of the école during the four years, "a direction about which nothing at present prevents me from answering." In fact Lacan remains its director until the dissolution in 1980. He divides the école into three sections: the section of pure psychoanalysis (training and elaboration of the theory, where members who have been analyzed but haven't become analysts can participate); the section for applied psychoanalysis (therapeutic and clinical, physicians who have neither completed nor started analysis are welcome); the section for taking inventory of the Freudian field (it concerns the critique of psychoanalytic literature and the analysis of the theoretical relations with related or affiliated sciences). To join the école, the candidate has to apply to an organized work-group: the cartel.

- “Proposition du 9 octobre 1967 sur le psychanalyste à l'Ecole,” Scilicet 1.

- Le séminaire, Livre XIV: La logique du fantasme, unpublished.

1968

- The novelty of the proposition of 1967 lies in the modification of access to the title of Analyst of the École (A.E.), a rank superior to that of Member Analyst of the École (A.M.E.). The analysts appointed as A.E. are those who have volunteered for the passe and have come victorious out of the trial. The passe consists of testifying, in front of two passeurs, to one's experience as an analysand and especially to the crucial moment of passage from the position of analysand to that of analyst. The passeurs are chosen by their analysts (generally analysts of the école) and should be at the same stage in their analytic experience as the passant. They listen to him and then, in turn, they testify to what they have heard in front of a committee for approval composed of the director, Lacan, and of some A.E. This committee's function is to select the analysts of the école and to elaborate, after the selecting process, a "work of doctrine."

- Le séminaire, Livre XV: L'acte psychanalytique, unpublished.

- The issue of the passe keeps invading the E.F.P.'s life. "Le quatrième groupe" is formed around those who resign from the E.F.P. disputing over Lacan's methods for the analysts' training and accreditation. Lacan takes a stand in the crisis of the university that follows May 1968: "If psychoanalysis cannot be articulated as a knowledge and taught as such, it 
has no place in the university, where it is only a matter of knowledge." The E.N.S. director, Flacelière, finds an excuse to tell Lacan that he is no longer welcome at the E.N.S. at the beginning of the academic year. Moreover, Cahiers pour l'Analyse has to stop its publication, but Vincennes appears as an alternative. Michel Foucault asks Lacan to create and direct at Vincennes the Department of Psychoanalysis. Lacan suggests that S. Leclaire, rather than himself, should undertake the project. Classes start in January. Thanks to Lévi-Strauss Lacan moves his seminars to the law school at the Panthéon.

- Le séminaire, Livre XVI: D'un Autre à l'autre, unpublished. In there Lacan argues that "the Name-of-the-Father is a rift that remains wide open in my discourse, it is only known through an act of faith: there is no incarnation in the place of the Other."

- In his seminar L'envers de la psychanalyse Lacan establishes the four discourses: Master's, university's, hysteric's and the analyst's discourse. He discusses the Father of Totem and Taboo who is all love (or jouissance) and whose murder generates the love of the dead Father, a figure to whom he opposes both the Father presiding over the first idealization and the Father who enters the discourse of the Master and who is castrated from the origin. "The death of the father is the key to supreme jouissance, later identified with the mother as the aim to incest." Yet psychoanalysis is not constructed on the proposition 'to sleep with the mother' but on the death of the father as primal jouissance. The real father is not the biological one but he who upholds "the Real as impossible." In "Radiophonie, "Scilicet2/3, Lacan argues that "if language is the condition of the unconscious, the unconscious is the condition of linguistics." Freud anticipated Saussure and the Prague Circle by sticking to the letter of the patient's word, to jokes, to slips, by bringing into light the importance of condensation and displacement in the production of dreams. The unconscious states that "the subject is not the one who knows what he says." Whoever articulates the unconscious must say that it is either that or nothing.

- Le séminaire, Livre XVII: L'envers de la psychanalyse, Paris: Seuil, 1991.

- One novelty in Lacan's teaching is his return to the hysteric with Dora and la Belle Bouche erre (the Beautiful Mouth wanders and an allusion to the beautiful butcher's wife analyzed by Freud and carried on in La direction de la cure Three questions: the relation between jouissance and the desire for unfulfilled desire; the hysteric who 'makes the man' (or the Master) insofar as she constructs him as "a man prompted by the desire to know;" a new conception of the analytic treatment as a "hysterization of discourse."

- Le séminaire, Livre XVIII: D'un discours qui ne serait pas du semblant, unpublished.

- As to Lacan "in psychoanalysis (as well as in the unconscious) man knows nothing of woman, and woman nothing of man. The phallus epitomizes the point in myth where the sexual becomes the passion of the signifier." For him the structure is the body of the symbolic: "there is no sexual rapport, implies no sexual rapport that can be formulated in 
the structure." There is "no appropriate signifier to give substance to a formula of sexual rapport."

- "L'étourdit" Scilicet 4.

- Le séminaire, Livre XIX: ... ou pire, unpublished.

- In Encore Lacan argues that woman would only enter in the sexual rapport quoad matrem (as a mother) and man quoad castrationem (phallic jouissance). Hence there is no real rapport and love as well as speech make up for his absence. And he adds: "There is woman only as excluded by the nature of words,...for man she is on the side of truth and man does not know what to do with it." In Le savoir psychanalytique from 1972, Lacan argues: "I am not saying that speech exists because there is no sexual rapport. I am not saying either that there is no sexual rapport because speech is there. But there is no sexual rapport because speech functions on that level that analytic discourse reveals to be specific to speaking human beings. The importance, the preeminence of what makes sex a semblance, the semblance of men and women. Between man and love, there is woman; between man and woman, there is a world; between man and the world, there is a wall. What is at stake in a serious love relationship between a man and a woman is castration. Castration is the means of adaptation to survival."

- Le séminaire, Livre XX: Encore, Paris: Seuil, 1975.The Seminar, Book XX: On Feminine Sexuality, the Limits of Love and Knowledge: Encore, New York: Norton, 1998.

- The Vincennes Department of Psychoanalysis is renamed "Le Champ freudien;" Lacan, director, and Jacques-Alain Miller, president. In Télévision, Paris: Seuil, (the text is based on a broadcast on the ORTF produced by Benoît Jacquot) Lacan makes is famous statement: "I always speak the truth. Not the whole truth, because there's no way to say it all. Saying it all is materially impossible: words fail. Yet it is through this very impossibility that the truth holds to the real."Television, New York: Norton, 1990.

- Le séminaire, Livre XXI: Les non-dupes errent, unpublished.

1975

- Lacan travels to the United States where he lectures at Columbia University (Auditorium, School of International Affairs), general discussion at Yale University (Kanzer Seminar and Law School Auditorium) followed by another general discussion at the Massachusetts Institute of Technology.

- Le séminaire, Livre XXII: R.S.I. in Ornicar?

- Lacan posits that the notion of structure does not allow to create a common field uniting linguistics, ethnology and psychoanalysis. Linguistics has no hold over the unconscious because "it leaves as a blank that which produces effects in the unconscious: the objet a, the very focus of the analytical act, and of any act. "Only the discourse that is defined in 
the terms of psychoanalysis manifests the subject as other giving him the key to his division, whereas science, by making the subject a master, conceals him to the extent the the desire that gives way to him bars him from me without remedy." There is only one myth in Lacan's discourse: the Freudian Oedipus complex.

- Le séminaire, Livre XXIII: Le sinthome, in Ornicar?

1977

- Le séminaire, Livre XXIV: L'insu que sait de l'une bévue s'aile à mourre, in Ornicar?

1978

- Le séminaire, Livre XXV: Le moment de conclure. One session only published as "Une pratique de bavardage," Ornicar?

1979

- Le séminaire, Livre XXVI: La topologie et le temps, unpublished.

1980

- On January 9, Lacan announces the dissolution of the EFP in a letter addressed to members and published in Le Monde. He asks those who wish to continue working with him to state their intentions in writing. He receives over one thousand letters within a week. On February 21, Lacan announces the founding of "La Cause freudienne." In July he attends an international conference in Caracas. "I have come here before launching my Cause freudienne. It is up to you to be Lacanians if you wish; I am Freudian."

- Le séminaire, Livre XXVII: Dissolution, in Ornicar?

1981

- September 9, Lacan dies in Paris.

\section{REFERENCES}

Jacques Lacan. (2016). In Encyclopædia Britannica. Retrieved from https://www.britannica.com/biography/Jacques-Lacan

Jacques Lacan. (2016). Retrieved from http://www.lacan.com/rolleyes.htm

Lacan, J., "Letter of Dissolution". Television/ A Challenge to the Psychoanalytic Establishment, 129-131.

Lacan, J., "Overture to the 1st International Encounter of the Freudian Field" , Hurly-Burly 6.

Matthew Sharpe (2016) Jacques Lacan (1901-1981), Internet Encyclopedia of Philosophy, ISSN 2161-0002, Retrieved from, http://www.iep.utm.edu/lacweb/

\section{Photo Credit: Wikipedia.Org}

How to cite this article: A Patel (2016), Person of the Month: Jacques Lacan (1901-1981), International Journal of Indian Psychology, Volume 3, Issue 4, No. 56, ISSN 2348-5396 (e) ISSN: 2349-3429 (p), DIP: 18.01.001/20160304, ISBN: 978-1-365-23992-2 